\title{
Strategi Pengembangan Komponen Kurikulum Bahasa Arab
}

\author{
Mochamad Syaifudin \\ IAI al-Khoziny Buduran Sidoarjo \\ Mochamadthole81@gmail.com
}

\begin{abstract}
This paper is intended to provide a holistic view on the strategies and processes of Arabic curriculum development component by reconcidering the foundations of its development. For this reason, this paper starts to reconsider the philosophical foundation, psychological foundation, socio-cultural foundation, science and technological foundation, which then be elaborated by mulling the principles of curriculum development component, which are relevance, flexibility, continuity, efficiency, and effectiveness. Hence, the process of Arabic curriculum development component could be executed through the approaches of academic, humanity, technology, and even social reconstruction. These approaches, for the author, are able to reconstruct the curriculum to be such a relevant and accommodative one toward the needs of society and the demands of today's era.
\end{abstract}

Keywords: developmental strategies; curriculum component; Arabic.

Abstrak: Tulisan ini bermaksud untuk memberikan gambaran utuh mengenai strategi dan proses pengembangan komponen kurikulum bahasa Arab, dengan cara meninjau kembali landasan-landasan pengembangannya, mulai dari landasan filosofis, landasan psikologis, landasan sosial budaya, dan landasan perkembangan ilmu dan teknologi, kemudian dielaborasi dengan mempertimbangkan prinsipprinsip pengembangan komponen kurikulum, yaitu prinsip relevansi, fleksibilitas, kontinuitas, praktis/efisiensi, dan efektivitas. Dengan demikian, proses pengembangan komponen kurikulum bahasa Arab dapat dilakukan melalui pendekatan subjek akademis, humanistis, teknologis, dan rekonstruksi sosial. Pendekatan ini, menurut hemat penulis, mampu merekonstruksi kurikulum yang relevan dan akomodatif terdahap kebutuhan masayarakat dan tuntutan perkembangan zaman.

Kata kunci: strategi pengembangan, komponen kurikulum, bahasa arab 


\section{Pendahuluan}

Dunia Pembelajaran Bahasa Arab (PBA) sejatinya telah menghadapi banyak tantangan secara hilir mudik, yang harus terus diantisipasi dan dicarikan solusinya secara cerdas, mulai dari masalah status bahasa Arab yang konon dianggap sebagai bahasa marginal dan tertinggal, persoalan psikologi peserta didik yang kian hari menunjukkan potret buram, hingga berbagai isu nasional dan global, antara lain menyangkut kompetisi atau daya saing nasional dan global di bidang pendidikan bahasa, bongkar-pasang kurikulum di hampir setiap pergantian menteri yang nota bene semakin membingungkan kalangan bawah, liberalisasi dan kapitalisasi bahasa yang menghendaki institusi pendidikan bahasa mampu menyediakan jasa layanan pembelajaran bahasa yang out comenya siap dijadikan ajang komoditi yang sarat dengan rivalitas tidak sehat dan sebagainya.

Di sisi lain, diakui bahwa akhir-akhir ini pembelajaran bahasa Arab sudah mulai menjadi perhatian banyak kalangan (booming), tetapi anehnya mengapa bahasa Arab yang konon dikembangkan di MI/MTs/MA, atau pada jenjang yang lebih tinggi di PTAI/IAIN/UIN justru semakin kurang diminati putra-putri muslim. Padahal, putra-putri muslimlah yang seharusnya paling berminat mempelajari bahasa kitab suci mereka, tetapi kenyataannya tidak demikian. Tentunya ada sesuatu yang mengganjal, yang dalam bahasa Muhamimin diistilahkan "something wrong"?!

Masalah pendidikan bahasa Arab memang tidak akan pernah the end untuk digali dan dibicarakan sampai kapan pun. Hal ini setidak-tidaknya didasarkan pada beberapa alasan:

Pertama, adalah merupakan fitrah setiap orang bahwa mereka menginginkan pendidikan yang lebih baik sekalipun mereka kadang-kadang belum tahu mana sebenarnya pendidikan yang lebih baik itu. Karena merupakan fitrah, sehingga sudah menjadi takdirnya pendidikan itu tidak pernah selesai diperbincangkan.

Kedua, teori-teori pendidikan akan selalu ketinggalan zaman, karena ia dibuat berdasarkan kebutuhan masyarakat yang selalu berubah pada setiap tempat dan waktu. Karena adanya perubahan itu maka masyarakat tidak pernah puas dengan teori pendidikan yang ada. 
Ketiga, perubahan pandangan hidup juga ikut berpengaruh terhadap ketidakpuasan seseorang akan keadaan pendidikan, sehingga pada suatu saat seseorang telah puas dengan sistem pendidikan yang ada karena sesuai dengan pandangan hidupnya, dan pada saat yang lain seseorang bisa terpengaruh oleh pandangan hidup lainnya yang pada gilirannya berubah pula pendapatnya tentang pendidikan yang semula dianggap memuaskannya tersebut. 1

Uraian di atas menggarisbawahi bahwa pengembangan komponen kurikulum merupakan suatu kegiatan yang tak pernah selesai, yang menurut Muhaimin harus dilakukan secara berkelanjutan baik dalam aspek perencanaan, implementasi maupun evaluasinya yang tidak hanya berhenti pada aspek curriculum plan (kurikulum sebagai dokumen), yang meliputi: (1) perumusan standar kompetensi lulusan; (2) penentuan serangkaian matakuliah serta bobot sksnya; (3) penyusunan silabus; dan (4) penyusunan satuan acara perkuliahan (SAP) dan/atau course outline, dan lain-lain. Sedangkan pada aspek actual curriculum atau kegiatan nyata biasanya terlupakan, seperti masalah proses pembelajaran, proses evaluasi (assessment) termasuk di dalamnya uji kompetensi, dan penciptaan suasana akademik. Padahal, apa artinya kurikulum sebagai dokumen jika tidak ditindaklanjuti dengan actual curriculum. Karena itu, dalam pengembangan komponen kurikulum ini seharusnya memperhatikan keduaduanya secara integratif.

Berdasarkan kerangka di atas, tulisan ini akan berusaha mengurai dua dimensi penting di atas (curriculum plan dan actual curriculum) dalam mengembangkan komponen-komponen kurikulum tersebut.

\section{Tinjauan Umum atas Komponen Kurikulum}

Pendidikan merupakan suatu sistem yang terbentuk dari komponenkomponen yang saling berinteraksi dan melaksanakan fungsinya tertentu dalam rangka mencapai tujuan yang telah ditetapkan. Apabila salah satu komponen pembentuk tidak berfungsi, maka proses pendidikan dalam mencapai tujuan pendidikan akan sulit tercapai.

1Tiga alasan mendasar ini dikutip dari makalah Muhaimin yang disajikan pada Orientasi Pengembangan Kurikulum Program Magister (S2) Pendidikan Agama Islam PPs STAIN Samarinda, Tgl. 12 Maret 2012. 
Salah satu komponen dalam sistem pendidikan adalah kurikulum. Kurikulum merupakan alat untuk mencapai tujuan pendidikan dan sekaligus sebagai pedoman dalam penyelenggaraan kegiatan pembelajaran untuk mencapai tujuan pendidikan.

Salah satu fungsi kurikulum ialah sebagai akar untuk mencapai tujuan pendidikan. Kurikulum pada dasarnya memiliki komponen-komponen penunjang yang saling berkaitan dan berintegrasi satu sama lainnya dalam rangka mencapai tujuan tersebut. Subandijah mengatakan bahwa ada lima komponen kurikulum yaitu, tujuan, isi atau materi, metode atau strategi, organanisasi dan system evaluasi ${ }^{2}$ :

Menurut Muhaimin ${ }^{3}$ kurikulum dapat dikelompokkan menjadi tiga kelompok utama, yaitu : (1) kelompok komponen-komponen dasar, (2) kelompok komponen-komponen pelaksanaan, (3) kelompok-kelompok pelaksana dan pendukung kurikulum.

\section{Konsep Pengembangan Komponen Kurikulum}

Pengertian Kurikulum

Kata "kurikulum" berasal dari bahasa Yunani yang semula digunakan dalam bidang olah raga, yaitu curriculum dalam bahasa Yunani berasal dari kata curir, artinya pelari dan curere, artinya tempat berpacu. Curriculum yang berarti jarak yang harus ditempuh oleh pelari. Jadi, kurikulum dalam pendidikan diartikan sejumlah mata pelajaran yang harus ditempuh/ diselesaikan anak didik untuk memperoleh ijazah4 Dalam bahasa Arab istilah " kurikulum” diartikan dengan manhaj, yakni jalan yang terang, atau jalan terang yang dilalui oleh manusia pada bidang kehidupannya. ${ }^{5}$

\footnotetext{
2 Subandijah, Pengembangan dan Inovasi kurikulum, Cet. 1, Jakarta, PT. Raja Grafindo, 1993, hal. 93.

3 Muhaimin, Konsep Pendidikan Islam : Sebuah Telaah Komponen dasar Kurikulum, Solo, Ramadhani, 1991), hlm 11-12.

4 Nana Sudjana, Pembinaan dan Pengembangan Kurikulum di Sekolah, (Bandung: Sinar Baru Algesindo. 2008), cet.ke-6, hlm. 4.

5 (Muhaimin, Pengembangan Kurikulum Pendidikan Agama Islam di Sekolah, Madrasah, dan Perguruan Tinggi, (Jakarta: Rajagrafindo Persada. 2005), hlm. 1.
} 
Secara terminologi, para ahli pendidikan telah banyak mendefinisikan kurikulum, antara lain:

Pertama, Addamardasyi Sarhan dan Munir Kamil dalam Al-Syaibani6 bahwa kurikulum adalah sejumlah pengalaman pendidikan, kebudayaan, sosial, olah raga, dan kesenian yang disediakan oleh sekolah bagi murid-muridnya di dalam dan di luar sekolah dengan maksud menolong untuk berkembang menyeluruh dalam segala segi dan merubah tingkah laku mereka sesuai dengan tujuan-tujuan pendidikan.

Kedua, M. Arifin memandang kurikulum sebagai seluruh bahan pelajaran yang harus disajikan dalam proses kependidikan dalam suatu sistem institusional pendidikan. ${ }^{7}$ Nampaknya pengertian ini terlihat sederhana dan lebih menitikberatkan pada materi/ bahan pelajaran semata.

Ketiga, Zakiah Daradjat memandang kurikulum sebagai suatu program pendidikan yang direncanakan dan dilaksanakan untuk mencapai sejumlah tujuantujuan pendidikan tertentu. ${ }^{8}$. Pengertian kurikulum ini nampaknya lebih luas dari yang awal, karena di sini kurikulum tidak hanya dipandang dalam artian materi pelajaran, namun juga mencakup seluruh program di dalam kegiatan pendidikan.

Definisi tentang kurikulum yang dikemukakan tersebut menekankan bahwa kurikulum merupakan sejumlah materi pelajaran atau isi pelajaran, sejumlah pengalaman belajar, dan sejumlah program perencanaan pendidikan yang harus dicapai oleh peserta didik dalam rangka pencapaian tujuan pendidikan tertentu.

Nampaknya konsep dasar kurikulum tidak terbatas pada program pendidikan tersebut, namun juga dapat diartikan menurut fungsinya sebagaimana terdapat dalam pengertian "sebagai bahan pembanding ${ }^{9}$, sebagai program studi, sebagai konten, sebagai kegiatan berencana, sebagai hasil belajar, sebagai reproduksi cultural, sebagai pengalaman belajar dan sebagai produksi yang

6 Omar Muhammad Al-Toumy Al-Syaibany, Falsafatut Tarbiyyah al-Islamiyah, terj. Hasan Langgulung, Filsafat Pendidikan Islam, (Jakarta: Bulan Bintang. 1979), hlm. 485.

7 H.M. Arifin, Ilmu Pendidikan Islam, Tinjauan Teoritis dan Paraktis Berdasarkan Pendekatan Interdisipliner, (Jakarta: Bumi Aksara. 2008), cet.ke-3, hlm. 135.

8 Zakiah Daradjat, et al., Ilmu Pendidikan Islam, (Jakarta: Bumi Aksara. 2009), cet. ke-9, hlm. 122

9 Anonimous, Undang- undang Sistem Pendidikan Nasional No. 20 Tahun 2003, (Jakarta: Sinar Grafika. 2003), hlm.4.). 
pengertiannya adalah seperangkat tugas yang harus dilakukan untuk mencapai hasil yang ditetapkan terlebih dahulu ${ }^{10}$.

Pengertian Pengembangan Komponen Kurikulum

Dalam Kamus Bahasa Indonesia kata "pengembangan" mengandung arti hal mengembangkan; pembangunan secara bertahap dan teratur, dan yang menjurus ke sasaran yang dikehendaki. ${ }^{11}$

Pengembangan kurikulum mengandung pengertian sebagai kegiatan menghasilkan komponen kurikulum, yaitu sebuah proses yang mengaitkan satu komponen dengan yang lainnya untuk menghasilkan kurikulum yang lebih baik, dan atau kegiatan penyusunan (desain), pelaksanaan, penilaian, dan penyempurnaan kurikulum. ${ }^{12}$

Dengan demikian, pengembangan komponen kurikulum dalam pendidikan bahasa Arab berarti suatu upaya atau proses untuk mengembangkan atau menghasilkan kurikulum pendidikan bahasa Arab yang lebih baik.

\section{Landasan dan Prinsip Pengembangan Komponen Kurikulum}

Kurikulum sebagai rancangan pendidikan mempunyai kedudukan yang cukup sentral dalam seluruh kegiatan pendidikan, menentukan proses pelaksanaan dan hasil pendidikan. Implikasinya bahwa penyusunan kurikulum dan segala komponennya tidak dikerjakan apa adanya, akan tetapi memerlukan landasan-landasan yang dijadikan dasar dalam pengembangan komponen kurikulum.

Landasan-landasan tersebut yaitu landasan filosofis, landasan psikologis, landasan sosial budaya, dan landasan perkembangan ilmu dan teknologi. ${ }^{13}$

\footnotetext{
10 Muhaimin dan Abdul Mujib, Pemikiran Pendidikan Islam, Kajian Filosofik dan Kerangka Dasar Operasionalnya, (Bandung: Trigenda Karya. 1993), hlm. 185.

11 Dedi Sugono et. al., Kamus Bahasa Indonesia. (Jakarta: Pusat Bahasa. 2008), hlm. 725.

12 Muhaimin, Pengembangan Kurikulum, hlm. 10

13 Nana Syaodih Sukmadinata, Pengembangan Kurikulum, Teori dan Praktek, (Bandung: Remaja Rosdakarya. 2002), cet. ke-5, hlm. 38.
} 
Pertama: Landasan Filosofis: Pendidikan berintikan interaksi antar manusia, antara pendidik dan terdidik untuk mencapai tujuan pendidikan. Dalam interaksi tersebut terlibat isi yang diinteraksikan serta proses bagaimana interaksi tersebut berlangsung. Hal ini memerlukan pengkajian mendasar yang bersifat filosofis.

Kedua: Landasan Psikologis: Dalam proses pendidikan terjadi interaksi antar individu manusia yaitu antara peserta didik dengan pendidik dan antara peserta didik dengan yang lainnya. Manusia berbeda dengan makluk lainnya karena kondisi psikologisnya. Manusia memiliki kondisi psikologis yang lebih tinggi tarafnya dan kompleks dibandingkan dengan makhluk lainnya, sehingga manusia menjadi lebih maju, lebih banyak memiliki kecakapan, pengetahuan, dan keterampilan, dibandingkan dengan binatang.

Kondisi psikologis merupakan karakteristik psiko-fisik seseorang sebagai individu, yang dinyatakan dalam berbagai bentuk prilaku dalam interaksi dengan lingkungannya. Perilaku-perilaku tersebut merupakan manifestasi dari ciri-ciri kehidupannya, baik yang tampak maupaun yang tidak Nampak, perilaku kognitif, afektif, dan psikomotor. ${ }^{14}$

Ketiga, Landasan Sosial Budaya: Konsep pendidikan bersifat universal, akan tetapi pelaksananaan pendidikan disesuaikan dengan situasi dan kondisi masyarakat setempat. Maka setiap lingkungan memiliki sistem sosial budaya yang berbeda. Sistem sosial budaya mengatur pola kehidupan dan pola hubungan antar anggota masyarakat, antar anggota dan lembaga, dan antar lembaga dengan lembaga.

Keempat, Landasan Perkembangan Ilmu dan Teknologi: Perkembangan ilmu dan teknologi tiap waktu megalami perubahan dan perkembangan. Pengembangan suatu ilmu pengetahuan tidak hanya ditujukan untuk perkembangan ilmu pengetahuan itu sendiri, melainkan juga diharapkan dapat memberikan sumbangan kepada bidang-bidang kehidupan atau ilmu yang lainnya.

Perkembangan ilmu pengetahuan dan teknologi berpengaruh cukup besar terhadap pendidikan. Pendidikan sangat erat hubungan dengan kehidupan sosial, 
sebab pendidikan merupakan salah satu aspek sosial. Pendidikan berupaya meningkatkan pengetahuan dan kecakapan, memperoleh keterampilan dan membentuk sikap-sikap tertentu.

Adapun prinsip-prinsip pengembangan komponen kurikulum juga tidak berbeda dengan prinsip-prinsip pengembangan kurikulum yang antara lain dikemukakan oleh Zakiah Daradjat ${ }^{15}$ sebagai berikut: 1) Prinsip relevansi; dalam arti kesesuaian pendidikan dalam lingkungan hidup murid, relevansi dengan kehidupan masa sekarang dan akan datang, dan relevansi dengan tuntutan pekerjaan. 2) Prinsip efektivitas; baik efektifitas mengajar guru, ataupun efektifitas belajar murid. 3) Prinsip efisiensi; baik dalam segi waktu, tenaga, dan biaya. 4) Prinsip fleksibilitas, artinya ada semacam ruang gerak yang memberikan sedikit kebebasan dalam bertindak, baik yang berorientasi pada flesksibilitas pemilihan program pendidikan maupun dalam mengembangkan program pengajaran.

Jika kurikulum pendidikan bahasa Arab diformulasikan sedemikian rupa dengan mengacu kepada dasar-dasar dan prinsip-prinsip yang telah penulis paparkan di atas, maka harapan untuk berhasil tercapainya tujuan-tujuan yang diharapkan cukup besar.

\section{Pengembangan Komponen Kurikulum PBA}

Dalam Undang-undang Sisdiknas No 20 Tahun 2003, nampak bahwa kurikulum ini memuat rencana-rencana dan prosedur tentang tujuan, isi, materi, dan cara dalam penyelenggaran kegiatan pembelajaran. Dengan kata lain, termuat komponen-komponen kurikulum yaitu tujuan, isi, materi, organisasi, dan evaluasi.

Demikian juga pandangan yang diutarakan oleh Oemar Hamalik, bahwa komponen kurikulum mencakup lima aspek; (1) tujuan, (2) isi, (3) materi, (4) organisasi kurikulum dan (5) evaluasi. Kelima komponen tersebut memiliki keterkaitan yang erat dan tidak bisa dipisahkan. ${ }^{16}$

15 Daradjat, et al. Ilmu Pendidikan, hlm. 125-127

16 Oemar hamalik, Kurikulum dan Pembelajaran (Jakarta, bumi aksara, 2012). Cetakan ke-12, hlm. 23-24. 
Hanya saja pendapat di atas belum mencapai kata final sebab para ahli berbeda pendapat dalam menetapkan komponen-komponen kurikulum. Ada yang mengemukakan 5 komponen dan ada yang mengemukakan hanya 4 komponen. Di antara yang menyatakan bahwa komponen kurikulum terdiri atas 5 komponen ialah; Subandiyah (1993), Subandijah (1993), Oemar Hamalik (2012) dan yang lainnya.

Sementara yang pro dengan 4 komponen ialah Soemanto (1982), Nasution (1988), Fuaduddin dan Karya (1992), Nana Sudjana (1991), Hasan Langgulung (1988), Ramayulis (2011) dan yang lainnya.

Walaupun istilah komponen yang dikemukakan berbeda, namun pada intinya sama yakni: (1) Tujuan; (2) Isi dan struktur kurikulum; (3) Strategi pelaksanaan dan: (4) Evaluasi.

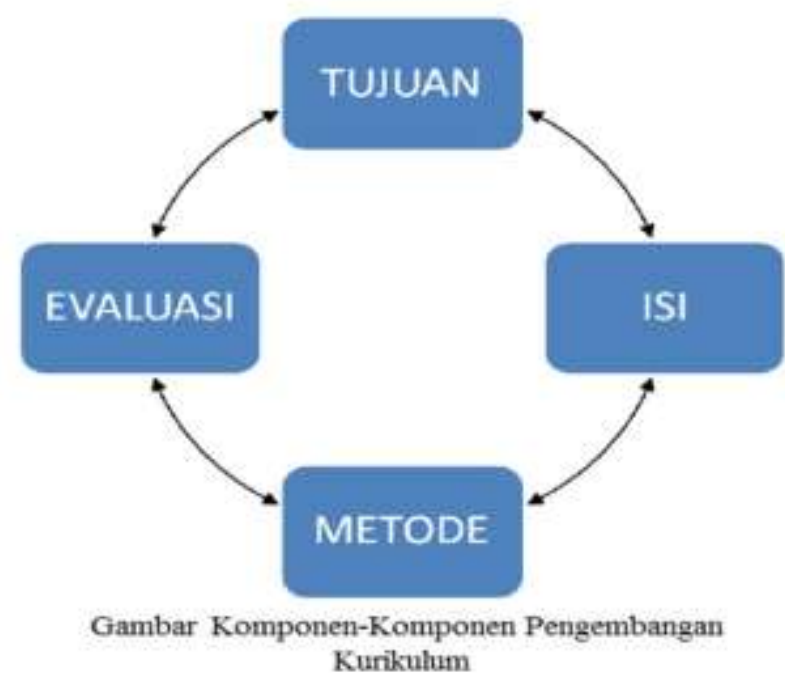

\section{Komponen tujuan}

Tujuan merupakan hal yang ingin dicapai oleh sekolah secara keseluruhan yang mencakup tiga dimensi yaitu dimensi kognitif, afektif, dan psikomotorik. Secara hirarkis tujuan pendidikan tersebut dari yang paling tinggi sampai yang paling rendah yaitu dapat diurutkan sebagai berikut: 1) Tingkat pendidikan nasional. 2) Tingkat institusional, tujuan kelembagaan. 3) Tujuan kurikuler (tujuan mata pelajaran atau bidang studi. 4) Tujuan instruksional (tujuan pembelajaran) yang terdiri dari (a) Tujuan pembelajaran umum (TPU), (b) Tujuan pembelajaran khusus (TPK). 
Adapun tujuan pendidikan nasional telah yang tercantum dalam UU no. 2 tahun 1989 pasal 4 yang berbunyi:

"Pendidikan naisional bertujuan mencerdaskan kehidupan bangsa dan mengembangkan manusia Indonesia seutuhnya, yaitu manusia yang beriman yang bertakwa kepada Tuhan Yang Maha Esa dan berbudi pekerti luhur, memiliki pengetahuan dan keterampilan, kesehatan jasmani dan rohani, berkepribadian yang mantap dan mandiri serta bertanggung jawab kemasyarakatan dan kcebangsaan" .

Sedangkan dalam UU RI no. 20 tahun 2003 pasal 3 tentang sisdiknas tujuan pendidikan nasional adalah:

"Pendidikan nasional bertujuan untuk berkembangnya potensi peserta didik agar menjadi manusia yang beriman dan bertakwa kepada Tuhan yang maha Esa, berakhlak mulia, sehat, berilmu, cakap, kreatif, mandiri, dan menjadi warg Negara yang demokratis serta bertanggung jawab".

Tujuan pendidikan di atas pada dasarnya ialah untuk membentuk peserta didik untuk menjadi manusia seutuhnya (insan kamil) yang mempunyai ilmu pengetahuan dan teknologi serta beriman dan bertakwa atau dalam istilah orde baru yaitu pancasilais. Tujuan tesebut mempunyai tujuan yang komprehensip di hampir semua lini.

Insan kamil yang dimaksud adalah manusia yang bercirikan dua hal penting: Pertama manusia yang seimbang, memiliki keterpaduan dua dimensi kepribadian, Kedua, manusia seimbang yang memiliki keseimbangan dalam kualitas fikir Zikir dan amal sholeh ${ }^{17}$. Jika komponen tujuan tersebut diterjemahkan dalam bentuk tabel, maka akan kita temukan hirarki tingkat tujuan berikut:

Tingkat pendidikan nasional
Tujuan Pendidikan Nasional dalam UU no. 2 tahun 1989 pasal 4:
"Pendidikan naisional bertujuan mencerdaskan kehidupan bangsa dan
mengembangkan manusia Indonesia seutuhnya, yaitu manusia yang
beriman yang bertakwa kepada Tuhan Yang Maha Esa dan berbudi
pekerti luhur, memiliki pengetahuan dan keterampilan, kesehatan
jasmani dan rohani, berkepribadian yang mantap dan mandiri serta
bertanggung jawab kemasyarakatan dan kebangsaan"

${ }^{17}$ Ahmadi, Islam Paradigma Ilmu pendidikan, Cet. 1, Yogyakarta, Aditya Medya, 1992, hal. 130. 


\section{Tujuan Institut Agama Islam Negeri Sunan Ampel Surabaya:}

a. Menyiapkan mahasiswa agar menjadi anggota masyarakat yang memiliki akhlak karimah, kemampuan akademik dan/atau profesional yang dapat menerapkan, mengembangkan, dan/atau menciptakan ilmu-ilmu keislaman dan seni yang dijiwai oleh nilainilai keislaman.

b. Menyebarluaskan ilmu-ilmu keislaman dan seni yang dijiwai oleh nilai-nilai keislaman, serta mengupayakan penggunaannya untuk meningkatkan taraf kehidupan masyarakat dan memperkaya kebudayaan nasional.

\section{Tingkat Fakultas}

Tujuan Fak. Tarbiyah Institut Agama Islam Negeri Sunan Ampel Surabaya:

a. Menghasilkan sarjana pendidikan Islam yang profesional, unggul dan berdaya saing

b. Menghasilkan produk pemikiran dan pengembangan pendidikan Islam yang uptodate dan inovatif

c. Menghasilkan model layanan jasa pendidikan Islam yang berkualitas

\section{Tingkat Prodi}

\section{Tujuan Prodi PBA Fak Tarbiyah IAIN Sunan Ampel Surabaya:}

a. Meluluskan sarjana Pendidikan Bahasa Arab dengan ambang batas minimal $85 \%$ dengan tepat waktu

b. Meluluskan sarjana pendidikan bahasa Arab yang terserap didunia kerja batas minimal $75 \%$ dengan masa tunggu 6 bulan.

c. Meluluskan sarjana pendidikan bahasa Arab yang mampu menghasilkan karya dan publikasi ilmiah dalam bidang pendidikan bahasa Arab.

d. Menghasilkan sarjana pendidikan bahasa Arab yang mampu memberikan teladan dalam kehidupan atas dasar nilai-nilai Islam dan budaya luhur bangsa.

e. Menghasilkan sarjana pendidikan bahasa Arab yang smart, pious, honourable.

f. Menghasilkan pemikiran, teknologi dan sumber belajar pendidikan Bahasa Arab.

\section{Tingkat Komponen Utama \\ Tujuan Komponen Utama:}


Memiliki kecakapan dalam aspek metodologi pembelajaran bahasa Arab dan strategi pembelajarannya

\section{Tingkat Satuan Mata Kuliah \\ Tujuan Strategi Belajar Mengajar Bahasa Arab:}

Setelah selesai dari perkuliahan ini, diharapkan para mahasiswa program Pendidikan Bahasa Arab memiliki seperangkat pemahaman dan kemampuan mempraktekkan mengajar secara komprehensip tentang suatu kegiatan/aktivitas yang memungkinkan terjadinya kegiatan belajar mengajar dalam suatu situasi dan kondisi, di mana siswa dapat berinteraksi dengan guru dan/atau bahan pembelajaran di tempat tertentu yang telah diatur dalam rangka mencapai tujuan dengan melibatkan beberapa komponen instruksional.

Berdasarkan tujuan-tujuan di atas, baik tujuan secara umum maupun khusus, selanjutnya dapat ditetapkan melalui materi pembelajaran.

\section{Komponen Isi atau materi}

Materi kurikulum pada hakekatnya adalah isi kurikulum itu sendiri. Dalam sisdiknas disebutkan: "bahwa.... isi kurikulum merupakan bahan kajian dan pelajaran penyelenggaraan untuk mencapai suatu tujuan nasional. ${ }^{18}$

Fuaduddin mengemukakan beberapa kriteria yang digunakan untuk menyusun materi kurikulum, sebagai berikut:1) Continuitas (kesinambungan), 2) Sequences (urutan), 3) Intergration (keterpaduan), 4) Flexibility (keluesan atau kelenturan).

Kriteria yang diprogramkan bertujuan mencapai tujuan pendidikan yang telah ditetapkan. Disusun dan disusun sedemikian rupa sesuai dengan Scope dan Scuece-nya. Isi atau materi tersebut biasanya berupa materi mata pelajaran, seperti pendidikan agama Islam, yang meliputi hadits, fiqh, tarikh, bahasa Arab dan lain sebagainya. ${ }^{19}$

Menurut Oemar Hamalik, materi kurikulum mengandung aspek-aspek tertentu sesuai dengan tujuan kurikulum. Aspek-aspek ini sangat layak dijadikan

18 Oemar hamalik, Kurikulum dan Pembelajaran, hlm. 25.

19 Fuaduddin, Pengembangan dan Inovasi Kurikulum, Jakarta, Proyek pengemnagan Pendidika, Departemen pendidikan dan Kebudayaan, 1992, hal. 92. 
sebagai alat untuk menganalisa kelayakan materi Pembelajaran bahasa Arab. Di antara aspek-aspek tersebut adalah sebagai berikut:

Pertama, Aspek teori yaitu seperangkat konstruk atau konsep, definisi dan preposisi yang saling berhubungan. Demikian juga dalam pembelajaran bahasa Arab, aspek ini musti diterapkan dalam rangka mengembangkan komponen materi, misalnya, mengaitkan antara teori-teori kaidah bahasa dengan materi qiras'ah, muha>dathah hingga pada tes harian (seperti materi al-arqa>m al'arabiyyah yang dituangkan dalam bentuk kaidah al-adad wa al-ma'du>d, lalu dikaitkan dengan tema qaira>'ah, misalnya mengambil judul " $a l^{\prime} u n w a>n$ ", dan seterusnya),.

Kedua, Konsep yaitu abstraksi yang dibentuk oleh generalisasi dan kekhususan-kekhususan. Artinya, komponen materi pembelajaran bahasa Arab harus mempertimbangkan sebuah konsep yang dihasilkan melalui generalisasi dan khususan-kekhususan. Aspek ini bisa dikembangkan melalui penelitian-penelitian berbasis PBA, misalnya, melalui PTK, atau jenis-jenis penilitian kebahasaan, yang hasilnya kemudian dijadikan sebagai landasan atau konsep dasar dalam mengembangkan komponen materi, sesuai dengan kearifan lokal. Dengan begitu komponen materi dalam pembelajaran bahasa Arab lebih ramah lingkungan.

Ketiga, Generalisasi yaitu kesimpulan umum berdasarkan hal-hal yang khusus, yang bersumber dari analisis, pendapat atau pembuktian.

Keempat, Prinsip yaitu ide utama atau pola skema yang ada di dalam materi yang mengembangkan relasi antara beberapa konsep.

Kelima, Prosedur yaitu langkah-langkah yang berurutan dalam materi pelajaran bahasa Arab yang harus ditempuh oleh siswa. Dengan kata lain, komponen materi harus mempertimbangkan skala perioritas. Misalnya dalam skala materi ajar, materi tentang istima>' dan kala $>m$ lebih didahulukan dari pada materi qira $>$ 'ah dan kita>bah. Hingga pada level yang lebih luas, graduasi dan keterkaitan antara satu materi dengan materi lainnya mulai dari kelas VII hingga kelas IX dan seterusnya

Keenam, Fakta yaitu sejumlah informasi khusus dalam materi yang dianggap urgen. Artinya, komponen materi bahasa Arab yang akan disajikan kepada peserta didik hendaknya memperhatikan informasi-informasi aktual. Memang benar apa yang dikatakan oleh Muhammad Syaikh, bahwa komponen 
materi bahasa Arab harus mengacu pada budaya-budaya Arab, karena dengan memahami seluk-beluk budaya Arab peserta didik akan lebih mudah mempelajari bahasa ini, tetapi, prinsip ini tidak semerta-merta bias kita adopsi secara total, karena pada kenyataannya peserta didik lebih mudah mempelajari materi -qira'ah misalnya- melalui fakta-fakta sosial yang ada di sekitar mereka. Jika demikian, maka harus ada keseimbangan antara materi yang berbasis pada fakta sosial atau budaya dari bahasa sasaran dengan fakta sosial dan budaya yang ada di sekitar siswa.

Ketujuh, Istilah yaitu perbendaharaan kosakata baru yang diperkenalkan kepada peserta didik. Artinya materi kosa-kata bahasa Arab yang hendak dikonstruk dan disajikan kepada peserta didik musti memperhatikan prinsip sha>'i'ah dan relefan. Demikian juga istilah-istilah kebahasaan yang hendak disajikan. Karena kosakata dan istilah memiliki masanya tersediri.

Kedelapan, Contoh atau ilustrasi yaitu Suatu tindakan atau proses yang bertujuan untuk memperjelas suatu uraian. Maksudnya komponen materi harus menyajikan seperangkat contoh yang ilustratif, dengan demikian siswa akan lebih mudah menangkap materi. Terutama materi-materi yang terkait dengan sistem fonetik, morfologi, sintaksis maupun semantik.

Kesembilan, Definisi yaitu penjelasan tentang makna atau pengertian tentang sesuatu kata dalam garis besarnya. Maksudnya komponen materi bahasa Arab hendaknya menyajikan definsi-definisi, terutama terkait istilah-istilah yang berpotensi menimbulkan ambiguitas di kalangan siswa. ${ }^{20}$

\section{Komponen Metode atau Strategi}

Metode dan Strategi pengajaran bahasa arab yang dimaksudkan di sini tidak hanya terbatas pada bagaimana mengajarkan bahasa arab dengan strategi dan metode yang sesuai, tetapi menyangkut berbagai macam aktifitas yang diusahakan oleh guru dalam membelajarakan siswa. Dengan kata lain mengatur seluruh komponen, baik pokok maupun penunjang dalam sistem pengajaran bahasa Arab.

20 Oemar Hamalik,Teknik Pengukuran dan Evaluasi Pendidikan (Bandung, Mandar Maju, 1989), hlm 84-86). 
Komponen metode atau strategi menempati fungsi yang penting dalam kurikulum, karena memuat tugas-tugas yang perlu implementasikan oleh peserta didik dan guru, karena itu, menurut Hamalik, penyusunannya hendaknya mengacu pada analisis tugas yang mengacu pada tujuan kurikulum dan berdasarkan prilaku awal peserta didik. Dalam hubungan ini ada tiga alternatif pendekatan yang dapat digunakan21: a) Pendekatan yang berpusat pada mata pelajaran, b) Pendekatan yang berpusat pada siswa, c) Dan pendekatan yang berorientasi pada kehidupan masyarakat.

\section{Komponen Evaluasi}

Dalam pengertian terbatas, evaluasi kurikulum dimaksudkan untuk memeriksa tingkat ketercapaian tujuan-tujuan pendidikan yang ingin diwujudkan melalui kurikulum yang bersangkutan. Sedangkan dalam pengertian yang lebih luas, evaluasi kurikulum dimaksudkan untuk memeriksa kinerja kurikulum secara keseluruhan ditinjau dari berbagai kriteria.

Dalam pembelajaran bahasa Arab, evaluasi termasuk salah satu komponen kurikulum yang memainkan peran penting dalam mewujudkan tujuan pembelajaran bahasa Arab yang telah ditetapkan. Komponen evaluasi merupakan bagian dari pembentuk kurikulum bahasa Arab yang berperan sebagai cara untuk mengukur atau melihat apakah tujuan pembelajaran bahasa Arab yang telah dibuat itu tercapai atau tidak. Selain itu, dengan melakukan evaluasi, kita dapat mengetahui apabila ada kesalahan pada materi yang diberikan atau metode yang digunakan dalam menjalankan kurikulum bahasa Arab yang telah dibuat dengan melihat hasil dari evaluasi tersebut. Dengan begitu, kita juga dapat segera memperbaiki kesalahan yang ada atau mempertahankan bahkan meningkatkan hal-hal yang sudah baik atau berhasil.

Di samping itu, terdapat beberapa model evaluasi kurikulum, diantaranya adalah Model CIPP (Context, Input, Process dan Product) yang bertitik tolak pada pandangan bahwa keberhasilan progran pendidikan dipengaruhi oleh berbagai faktor, seperti: karakteristik peserta didik dan lingkungan, tujuan program dan peralatan yang digunakan, prosedur dan mekanisme pelaksanaan program itu

\footnotetext{
21 Oemar Hamalik, Kurikulum dan Pembelajaran, hlm 27.
} 
sendiri. Evaluasi model ini bermaksud membandingkan kinerja (performance) dari berbagai dimensi program dengan sejumlah kriteria tertentu, untuk akhirnya sampai pada deskripsi dan judgment mengenai kekuatan dan kelemahan program yang dievaluasi. Model ini kembangkan oleh Stufflebeam menggolongkan program pendidikan atas empat dimensi, yaitu : Context, Input, Process dan Product. Menurut model ini keempat dimensi program tersebut perlu dievaluasi sebelum, selama dan sesudah program pendidikan dikembangkan. Penjelasan singkat dari keempat dimensi tersebut adalah, sebagai berikut :

Context; yaitu situasi atau latar belakang yang mempengaruhi jenis-jenis tujuan dan strategi pendidikan yang akan dikembangkan dalam program yang bersangkutan, seperti : kebijakan departemen atau unit kerja yang bersangkutan, sasaran yang ingin dicapai oleh unit kerja dalam kurun waktu tertentu, masalah ketenagaan yang dihadapi dalam unit kerja yang bersangkutan, dan sebagainya.

Input; bahan, peralatan, fasilitas yang disiapkan untuk keperluan pendidikan, seperti : dokumen kurikulum, dan materi pembelajaran yang dikembangkan, staf pengajar, sarana dan pra sarana, media pendidikan yang digunakan dan sebagainya.

Process; pelaksanaan nyata dari program pendidikan tersebut, meliputi: pelaksanaan proses belajar mengajar, pelaksanaan evaluasi yang dilakukan oleh para pengajar, penglolaan program, dan lain-lain.

Product: keseluruhan hasil yang dicapai oleh program pendidikan, mencakup : jangka pendek dan jangka lebih panjang

Demikianlah empat komponen utama pengembangan kurikulum. Di sini penulis akan menambahkan satu lagi komponen yang tidak kalah pentingnya, sebagaimana yang diusulkan oleh Oemar Hamalik. Ia menambahkan satu komponen lagi yaitu komponen pengorganisasian kurikulum yang masing-masing memiliki ciri-ciri sendiri:

Pertama, Mata pelajaran terpisah (isolated subject); yaitu kurikulum terdiri dari sejumlah mata pelajaran yang terpisah-pisah, yang diajarkan sendiri-sendiri tanpa ada hubungan dengan mata pelajaran lainnya. Masing-masing diberikan 
pada waktu tertentu dan tidak mempertimbangkan minat, kebutuhan, dan kemampuan peserta didik, semua materi diberikan sama.

Kedua, Mata pelajaran berkorelasi (correlated); korelasi diadakan sebagai upaya untuk mengurangi kelemahan-kelemahan sebagai akibat pemisahan mata pelajaran. Prosedur yang ditempuh adalah menyampaikan pokok-pokok yang saling berkorelasi guna memudahkan peserta didik memahami pelajaran tertentu.

Ketiga, Bidang studi (broad field); yaitu organisasi kurikulum yang berupa pengumpulan beberapa mata pelajaran yang sejenis serta memiliki ciri-ciri yang sama dan dikorelasikan (difungsikan) dalam satu bidang pengajaran. Salah satu mata pelajaran dapat dijadikan "core subject", dan mata pelajaran lainnya dikorelasikan dengan core tersebut.

Keempat, Program yang berpusat pada anak (child centered), yaitu program kurikulum yang menitikberatkan pada kegiatan-kegiatan peserta didik, bukan pada mata pelajaran.

Kelima, Inti Masalah (core program), yaitu suatu program yang berupa unitunit masalah, dimana masalah-masalah diambil dari suatu mata pelajaran tertentu, dan mata pelajaran lainnya diberikan melalui kegiatan-kegiatan belajar dalam upaya memecahkan masalahnya. Mata pelajaran-mata pelajaran yang menjadi pisau analisisnya diberikan secara terintegrasi.

Keenam, Ecletic Program, yaitu suatu program yang mencari keseimbangan antara organisasi kurikulum yang terpusat pada mata pelajaran dan peserta didik. Berkenaan dengan Kurikulum Tingkat Satuan Pendidikan (KTSP), kalau ditinjau dalam perspektif madrasah/sekolah, tampaknya lebih cenderung menggunakan pengorganisasian yang bersifat eklektik, yang terbagi ke dalam lima kelompok mata pelajaran, yaitu (1) kelompok mata pelajaran agama dan akhlak mulia; (2) kelompok mata pelajaran kewarganegaraan dan kepribadian; (3) kelompok mata pelajaran ilmu pengetahuan dan teknologi; (4) kelompok mata pelajaran estetika; dan (5) kelompok mata pelajaran jasmani, olahraga dan kesehatan.

Kelompok-kelompok mata pelajaran tersebut selanjutnya dijabarkan lagi ke dalam sejumlah mata pelajaran tertentu, yang disesuaikan dengan jenjang dan jenis sekolah. Di samping itu, untuk memenuhi kebutuhan lokal disediakan mata 
pelajaran muatan lokal serta untuk kepentingan penyaluran bakat dan minat peserta didik disediakan kegiatan pengembangan diri. ${ }^{22}$

\section{Penutup}

Pengembangan komponen kurikulum pada pembelajaran bahasa Arab merupakan serangkaian proses kegiatan menghasilkan kurikulum, proses yang mengaitkan satu komponen dengan yang lainnya untuk menghasilkan kurikulum bahasa Arab yang lebih baik, dan atau kegiatan penyusunan, pelaksanaan, penilaian, dan penyempurnaan kurikulum bahasa Arab.

Proses pengembangan komponen kurikulum bahasa arab perlu memperhatikan landasan-landasan atau dasar-dasar pengembangan komponen kurikulum yaitu landasan filosofis, landasan psikologis, landasan sosial budaya, dan landasan perkembangan ilmu dan teknologi, dengan tetap memperhatikan prinsip-prinsip pengembangan komponen kurikulum, yaitu prinsip relevansi, fleksibilitas, kontinuitas, praktis/efisiensi, dan efektivitas.

Pengembangan komponen kurikulum bahasa Arab dapat dilakukan melalui pendekatan subjek akademis, humanistis, teknologis, dan rekonstruksi sosial. Pendekatan ini dapat digunakan sesuai dengan kebutuhan masayarakat dan tuntutan perkembangan zaman.

\section{DAFTAR PUSTAKA}

Ahmadi, Islam Paradigma Ilmu pendidikan. Yogyakarta: Aditya Medya, 1992.

Al-Syaibany, Omar Muhammad Al-Toumy, Falsafatut Tarbiyyah al-Islamiyah, terj. Hasan Langgulung, Filsafat Pendidikan Islam. Jakarta: Bulan Bintang. 1979.

Anonimous, Undang- undang Sistem Pendidikan Nasional No. 20 Tahun 2003. Jakarta: Sinar Grafika. 2003.

Arifin, H.M., Ilmu Pendidikan Islam, Tinjauan Teoritis dan Paraktis Berdasarkan Pendekatan Interdisipliner. Jakarta: Bumi Aksara, 2008.

Daradjat, Zakiah, et al., Ilmu Pendidikan Islam. Jakarta: Bumi Aksara, 2009.

22 Ibid, hlm 27-29. 
Fuaduddin, Pengembangan dan Inovasi Kurikulum. Jakarta: Proyek Pengembangan Pendidikan, Departemen pendidikan dan Kebudayaan, 1992.

Hamalik, Oemar, Teknik Pengukuran dan Evaluasi Pendidikan. Bandung: Mandar Maju, 1989.

Hamalik, Oemar. Kurikulum dan Pembelajaran. Jakarta: Bumi Aksara, 2012.

Muhaimin dan Abdul Mujib, Pemikiran Pendidikan Islam, Kajian Filosofik dan Kerangka Dasar Operasionalnya. Bandung: Trigenda Karya, 1993.

Muhaimin, Konsep Pendidikan Islam : Sebuah Telaah Komponen dasar Kurikulum. Solo: Ramadhani, 1991.

Muhaimin, Pengembangan Kurikulum Pendidikan Agama Islam di Sekolah, Madrasah, dan Perguruan Tinggi. Jakarta: Rajagrafindo Persada, 2005.

Subandijah, Pengembangan dan Inovasi kurikulum. Jakarta: PT. Raja Grafindo, 1993.

Sudjana, Nana. Pembinaan dan Pengembangan Kurikulum di Sekolah. Bandung: Sinar Baru Algesindo, 2008.

Sugono, Dedi, et. al., Kamus Bahasa Indonesia. Jakarta: Pusat Bahasa, 2008.

Sukmadinata, Nana Syaodih. Pengembangan Kurikulum, Teori dan Praktek. Bandung: Remaja Rosdakarya, 2002. 